\title{
A critical approach to the use of isolated liver cells for the study of metabolic events
}

\author{
By Christopher I. Pogson," William R. Carpenter, Jonathan S. Cook, \\ Michael J. Fisher, Michael A. Lomax, Mark Salter and John C. Stanley, \\ Department of Biochemistry, University of Manchester, Oxford Road, Manchester \\ $M_{13}{ }_{9} P L$
}

Although isolated cell preparations from adipose tissue had been introduced in 1964, it was not until after the publication of the paper by Berry \& Friend (1969) that the use of isolated liver cells became widespread. It is true that there are earlier reports of liver cell experiments (well reviewed by Bhargava, I968) but the problems of low yield and loss of metabolic function had proved major headaches before the advent of the collagenase $(E C$ 3.4.24.3)-based technique. The basic principles of cell isolation still remain unchanged although several, relatively minor, modifications have been introduced (Berry, I 974; Krebs et al. 1974; Elliott et al. 1976; Seglen, 1976; Elliott, 1979). Such has been the impact of this technique that symposia are now devoted to studies with liver cells, or, for those who prefer Greek, hepatocytes (Tager et al. 1976; Harris \& Cornell, 1983).

There seems little doubt that the isolated cell technique is, in principle, preferable to that based on the incubation of liver slices with collagenase (Sturdee et al. 1983). Slice techniques giving cells with reasonable viability have been elaborated (Fry et al. 1976; Ash \& Pogson, 1977; Bellemann et al. 1977) but it has proved possible to use perfusion even with large animal material (Lomax et al. I 983 ) and such inherently difficult preparations as human biopsy samples (Reese \& Byard, 1981; Guguen-Guillouzo et al. 1982, 1983; Byard et al. 1983).

Over the years there has been more general agreement as to which factors are important and which not in the perfusion-based procedure (see Pogson et al. 1983). What is not in doubt, however, is that it is essential that the viability of cell preparations be checked, if possible on each occasion. Viability is not easily defined, if only for the simple reason that any isolated cell must lack functions that are a consequence of cell-cell contact. A number of criteria have been used, and some of these are more critical than others. Measurement of dye exclusion is convenient (Berry \& Friend, 1969)-although not as easy as it at first appears (Seglen, 1976) - but gives over-optimistic estimates of the 'goodness' of any cell populations. Microscopic appearance is also somewhat misleading. Assay of enzyme content and comparison with that of whole liver may give erroneous estimates because of the number of cells which 'leak' small solutes but not macromolecules. Perhaps the best tests of viability are based on metabolic performance, particularly in respect of the pathway or process to be studied. Rates of gluconeogenesis and protein synthesis correlate well with other findings but are

-Present address: Wellcome Research Laboratories, Langley Court, Beckenham, Kent $\mathrm{BR}_{3}{ }_{3} \mathrm{BS}$. 
rather more complicated to measure than most would like. Both potassium ions and ATP contents again prove to be good indices, and the latter can be conveniently measured by luminescence assay with luciferase (Stanley \& Williams, I969).

An important question to be asked about the use of isolated liver cells is: 'To what extent are the properties of a complex, heterogeneous tissue retained in a homogeneous suspension of a single cell type ?'. The parenchymal cells comprise some $90 \%$ of the volume of the liver, although being only about $60 \%$ of the cell number. There are, however, physiological interactions between the reticuloendothelial, or Kupffer, cells and the parenchyma. Thus, endotoxin may have no effect on parenchymal cell populations unless they are supplemented with Kupffer cells as in vivo (Lowitt et al. I981; McCallum, I98I), probably because of the production of a mediator by the reticulo-endothelial cells.

Potentially even more serious, however, is the finding that parenchymal cells are by no means all alike, and that they are not distributed homogeneously throughout the liver (Jungermann \& Sasse, 1978; Jungermann \& Katz, 1982). The 'periportal' cells are predominantly gluconeogenic and the 'perivenous' cells correspondingly more glycolytic; the enzyme distributions and activities reflect these functional differences. The two categories of cells which may represent the extremes of a range can be partially separated by centrifugation techniques (e.g. Bengtsson $e t$ al . 198I). Jungermann's group have, however, found that a mixed, although apparently homogeneous, population of cells could be induced to become 'periportal' or 'perivenous' according to the hormonal conditions of the medium in which they were cultured for $48 \mathrm{~h}$ (Probst $e$ t al. 1982); the distribution of function in vivo may therefore be a response to the variations in the composition of the blood as it passes through the liver.

A suspension of parenchymal cells, therefore, must differ from whole liver in terms of detailed cell-cell interactions. Nevertheless, for very many purposes, this fundamental defect is not of great significance; there are few hepatic functions which have escaped investigation with isolated cell preparations. A major reason for this is that cell suspensions are homogeneous in the sense that it is possible to take large numbers of equivalent samples from the liver of one animal and to subject each to different treatments, for different times, at different temperatures, etc. Thus the amount of information that can be obtained from one preparation is very much greater than that from one whole liver whether in vivo or in vitro. The ease of screening drugs and specific effectors and of pursuing time-course, doseresponse and kinetic studies is a strong recommendation.

Liver cell suspensions have a limited useful life, even when supplemented with serum and other nutrients (Dickson \& Pogson, 1977). They are more stable, and can be stored, at $4^{\circ}$ and in less-oxygenated conditions (Farrell \& Lund, 1983); their loss of function may be associated with the generation of free radicals, a process stimulated by cysteine and ammonium ions (Viña et al. 1978, 1983). Attempts at long-term preservation have, so far, had limited success (Fuller et al. I980; Noviki et al. 1982). 
Isolated liver cells may be maintained for more prolonged periods, however, in culture dishes, although no growth should occur in such fully differentiated cells. The development of techniques involving the attachment of cells to collagen membranes (Sattler et al. 1978 ) permits the maintenance of cells for up to $4 \mathrm{~d}$; over longer periods, de-differentiation of function becomes increasingly apparent. Such maintenance cultures do, however, permit investigations of longer-term hormonal effects (Ichihara et al. 1982). Experiments with radiolabels become as economically feasible with these cultures as with the original cell suspensions.

Large tissues present problems for measurements of metabolite concentrations under steady-state conditions, mainly because of the difficulty of rapid quenching of intracellular enzymic activity. The use of dispersed cell suspensions is advantageous in allowing virtually immediate quenching with acid. In addition, new techniques have been devised to allow measurement of the concentrations of intermediates in the cytoplasmic and mitochondrial compartments, using digitonin or cavitational fractionation (Akerboom et al. 1979; Zuurendonk et al. 1979). Furthermore, cells may be rendered selectively permeable, either chemically with, for example, filipin (Gankema et al. 1981; Allan et al. 1983) or physically (electropermeabilization; Gordon \& Seglen, 1982); the latter technique, which allows cells to reseal spontaneously, has considerable promise.

It is now well recognized that freshly-isolated liver cells are metabolically deficient in a number of ways. In particular, a number of cellular intermediates are lost during the various preparative procedures. These include dicarboxylic acids (Cornell et al. 1974), reduced glutathione (Viña et al. 1978, 1983) and carnitine (Christiansen \& Bremer, 1976). To some extent, these losses may be reversed by addition of the relevant compound or its precursor and a period of pre-incubation. Other losses may occur over longer time-periods. Of particular significance is the rapid decline of cytochrome $\mathrm{P}_{450}$, a decline only reversible under special circumstances (Paine \& Hockin, r980; Nelson et al. 1982). Furthermore, polysomal disaggregation is a continuing phenomenon in incubations of liver cells (Dickson \& Pogson, 1980). Differences between experimental results with cells and whole tissue are perhaps most likely to be attributable to the loss of necessary intracellular metabolites or components, as much as to the absence of extracellular factors.

Incubations of liver cell suspensions are essentially static, i.e. the substrate concentrations decrease, and the product concentrations increase, as incubation proceeds. The desire for linear time-courses and for pseudo-steady-states has contributed to many experimenters using high, saturating, concentrations of substrates or hormones in such incubations. Although one should not disdain the information thus obtained, it is obvious that control processes operative in vivo may well be masked or overwhelmed by these arbitrary circumstances. Several attempts have been made to overcome this problem by devising 'superfusion', or 'perifusion', systems in which medium of appropriately physiological composition is passed continuously through a column of isolated cells (van der Meer \& Tager, 1976; McMenamy et al. 1981; Crisp et al. 1982). This principle has also been applied to monolayer cultures (Gebhardt \& Mecke, 1979). 
Many hepatic processes exhibit circadian rhythmicity. Although this aspect has not been widely investigated, a recent report has shown that 3-hydroxy-3methylglutaryl $C O A$ reductase (EC I.I.I.88) activity (which shows diurnal fluctuations in vivo) in rat liver cells is constantly at a high level whatever the time of isolation; this indicates that the control of rhythmicity may be lost during preparative procedures (Cighetti et al. 1983). Such reports dictate that some caution should be exercised in experiments involving similarly oscillating systems.

The foregoing paragraphs are intended to indicate the advantages and disadvantages of isolated liver cells as experimental material. In the second part of this survey, we will draw on experimental results from this laboratory to exemplify both these aspects.

\section{Aromatic amino acid metabolism}

In many ways, the field is almost ideally suited for liver-cell incubation systems. All the substrates are available with ${ }^{3} \mathrm{H}$ and ${ }^{14} \mathrm{C}$ labels in different positions in the molecule; all, being aromatic, are quantitatively adsorbed on to Norit GSX; and all give rise along their catabolic sequences to non-aromatic (non-charcoal-adsorbable) products including ${ }^{14} \mathrm{CO}_{2}$ and ${ }^{3} \mathrm{H}_{2} \mathrm{O}$. These factors permit the experimenter to incubate more than 100 samples at a time, because processing, subsequent to quenching with acid, merely consists of absorption of ${ }^{14} \mathrm{CO}_{2}$ with phenylethylamine, adsorption of aromatic compounds on to Norit GSX, brief centrifugation and removal of supernatant fractions for counting (e.g. Smith \& Pogson, I980; Dickson et al. 198I; Smith et al. 1981).

It is therefore relatively easy to measure the rate of metabolic flux through three segments of the tryptophan catabolic pathway: tryptophan 2,3-dioxygenase ( $E C$ I.I3.II.II), kynureninase (EC 3.7.I.3) and the sequence from 3-hydroxyanthranilate to the tricarboxylic acid cycle. From the differences between these one can gauge the rate of formation of various by-products or intermediates on diverging pathways. In this way we were able to correlate the inhibition of gluconeogenesis by tryptophan in rat liver with the accumulation of quinolinate, an intermediate in NAD synthesis (Smith et al. $198 \mathrm{r}$ ), and to show that the lack of such inhibition in some other species is associated with a greater oxidation of tryptophan and a very low rate of formation of quinolinate (Muñoz-Clares et al. I 98 I).

6-Chlorotryptophan is metabolized by liver to 4-chloro-3-hydroxyanthranilate, a very potent inhibitor of 3 -hydroxyanthranilate oxidase ( $E C$ I.10.3.5) in liver extracts (Parli et al. 1980). We were able to show that exposure of rat liver cells to 6-chlorotryptophan decreased the ability of exogenous tryptophan to inhibit gluconeogenesis, presumably by blocking the flux through 3 -hydroxyanthranilate oxidase to quinolinate (Cook \& Pogson, 1983 ). Similarly, addition of pyrazinamide, an inhibitor of picolinate carboxylase (EC 4.I.I.45), the enzyme controlling entry into the terminal segment of the tryptophan catabolic pathway, increased the efficacy of tryptophan as an inhibitor, probably by diversion of intermediates to quinolinate (Cook \& Pogson, I983). 


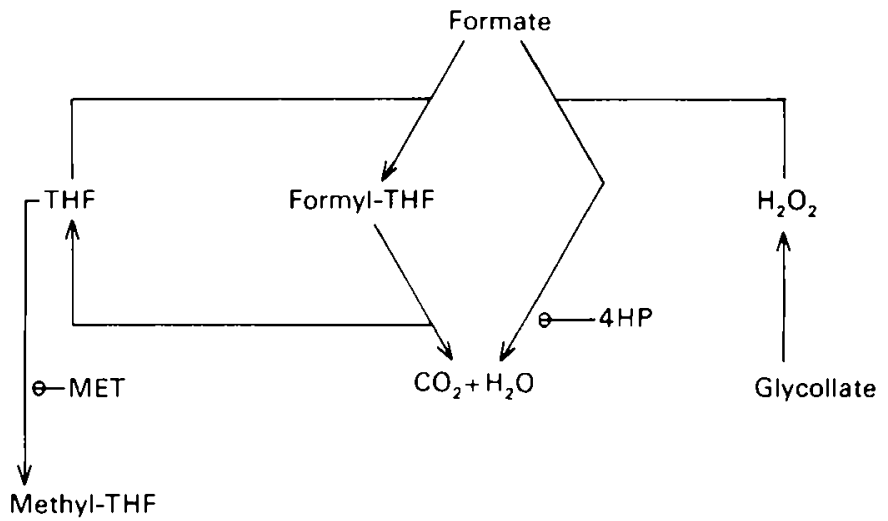

Fig. 1. Pathways of metabolism of formate in rat liver. ${ }_{4} \mathrm{HP}, 4$-hydroxypyrazole; MET, methionine; THF, tetrahydrofolate.

In a similar vein, we tested 4 -hydroxypyrazole as an inhibitor of tryptophan 2,3-dioxygenase. The enzyme was strongly inhibited in cells but, curiously, the ratio, ${ }^{14} \mathrm{CO}_{2}$ :non-aromatic products formed from $\mathrm{L}-\left[\right.$ ring-2- $\left.{ }^{14} \mathrm{C}\right]$ tryptophan was very markedly altered also, indicating a decreased capacity for oxidation of formate to $\mathrm{CO}_{2}$. Formate is normally oxidized through the intermediate formation of formyltetrahydrofolate, but can be oxidized directly by a catalase (EC I.I 1.1.6)-dependent pathway in folate-deficient rats (Fig. I; Palese \& Tephly, 1975). 4-Hydroxypyrazole is a known inhibitor of catalase, and blocks the catalase-dependent pathway, even when it is stimulated by glycollate (which generates hydrogen peroxide). Methionine, which overcomes the 'methyl trap' and thereby augments the availability of tetrahydrofolate, increases formate oxidation, and this increase is insensitive to 4 -hydroxypyrazole (Fig. I; Cook \& Pogson, 1982). Similarly, histidine catabolism, which also generates $C_{1}$ moieties is, in isolated cells, inhibited by 4 -hydroxypyrazole; methionine relieves this inhibition and stimulates oxidation markedly (Krebs et al. 1976; Cook \& Pogson, 1981). This phenomenon reflects entirely on the behaviour of the cell preparation for, in vivo, methionine is a normal plasma constituent and will maintain the folate pool in a state whereby catalatic oxidation of formate is negligible.

Tryptophan 2,3-dioxygenase catalyses the rate-limiting step in the irreversible removal of tryptophan from the circulation and, as such, 'requires' to be closely regulated. The mechanism of action of the dioxygenase is complex, so that it is far from clear that experiments in cell-free systems are fully relevant to physiological control. Use of isolated cells has cnabled us to examine the effects of variations in diet and hormonal environment on flux through the dioxygenase and to compare these with changes in enzyme activity assayed in cell homogenates. Fig. 2 shows that, at a physiologically-relevant concentration of tryptophan, tryptophan dioxygenase exhibits a substantial proportion of its maximal activity - especially if factors such as the Michaelis constant $\left(K_{m}\right)$ for tryptophan in cells are taken into account. Although this remains generally true for a number of conditions, there are 


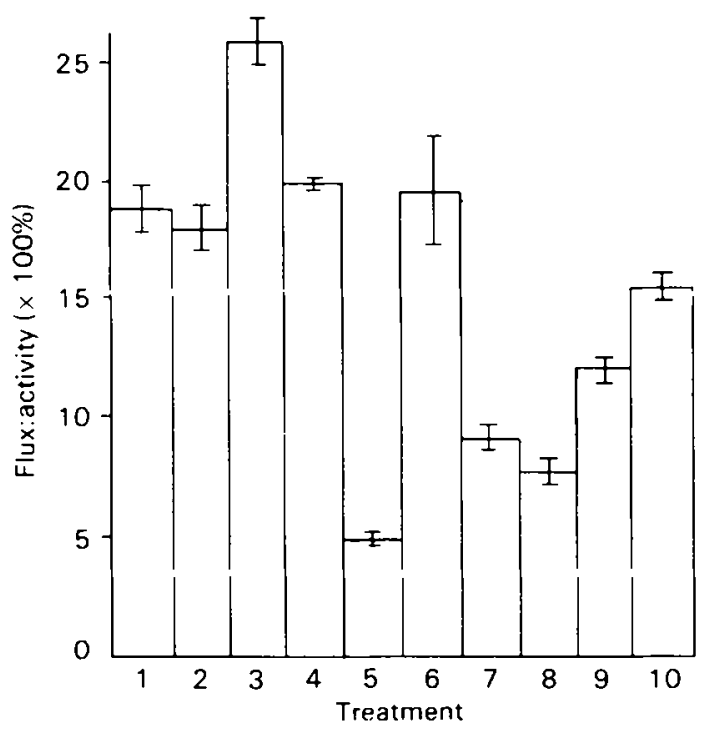

Fig. 2. Relationship between assayable tryptophan 2,3-dioxygenase ( $E C$ I.I3.II.I I) activity and flux through the enzyme in isolated rat liver cells. Treatment of rats: 1, fed; $2,48 \mathrm{~h}$ starved; 3 , pyridoxine control; 4 , pyridoxine deficient; 5 , tryptophan; 6 , adrenalectomy; 7 , adrenalectomy + steroid; 8,3 d diabetes; 9 , 10 d diabetes; 10 , 10 d diabetes + insulin.

Cells were incubated with $100 \mu \mathrm{M}-\mathrm{L}-$ tryptophan and $20 \mathrm{~g}$ albumin/1. Rats were Sprague-Dawley, males, $150-220 \mathrm{~g}$, given standard laboratory diet. The control diet for pyridoxine deficiency contained more protein than the standard diet. Tryptophan was given as two doses of $750 \mathrm{mg} / \mathrm{kg}$ body-weight, $6 \mathrm{~h}$ apart with the second injection $6 \mathrm{~h}$ before the experiment. Dexamethasone phosphate $\left(0.5 \mathrm{mg} /\right.$ animal) was injected subcutaneously daily for $5^{-8} \mathrm{~d}$ into adrenalectomized animals. Diabetes was induced by intravenous injection of streptozotocin ( $80 \mathrm{mg} / \mathrm{kg}$ body-weight). Insulin was given intraperitoneally as follows: 2 i.u. $24 \mathrm{~h}$ after streptozotocin, then daily for $3 \mathrm{~d}$; thereafter 3.5 i.u. were injected twice daily.

some exceptions. Animals pretreated with tryptophan display very greatly increased enzyme levels while tryptophan oxidation increases relatively little (Fig. 2). One explanation for this may be that tryptophan increases the amount of the total pyridine nucleotide pool (Bender et al. I982) and that the reduced nucleotides inhibit the dioxygenase by an allosteric mechanism (Cho-Chung \& Pitot, 1967). The changes in the ratio, flux:activity with steroid administration or in acute diabetes are not easily interpreted and are currently under investigation. One possibility is that intracellular haem synthesis may be a limiting factor (Badawy et al. I98I), as well as availability of pyridine nucleotide (Badawy, 1981). The experimental system, however, proves itself in that it highlights the areas requiring further work.

Fig. 3 shows the ratio, flux through picolinate carboxylase to the tricarboxylic acid cycle (the lower part of the pathway):flux through tryptophan 2,3-dioxygenase under various conditions, i.e. it compares the amount of tryptophan fully oxidized with that entering the pathway. In the control state with standard diet, only about $15 \%$ of the tryptophan metabolized is converted to non-aromatic products through picolinate carboxylase. The same holds for most conditions, except that of chronic 


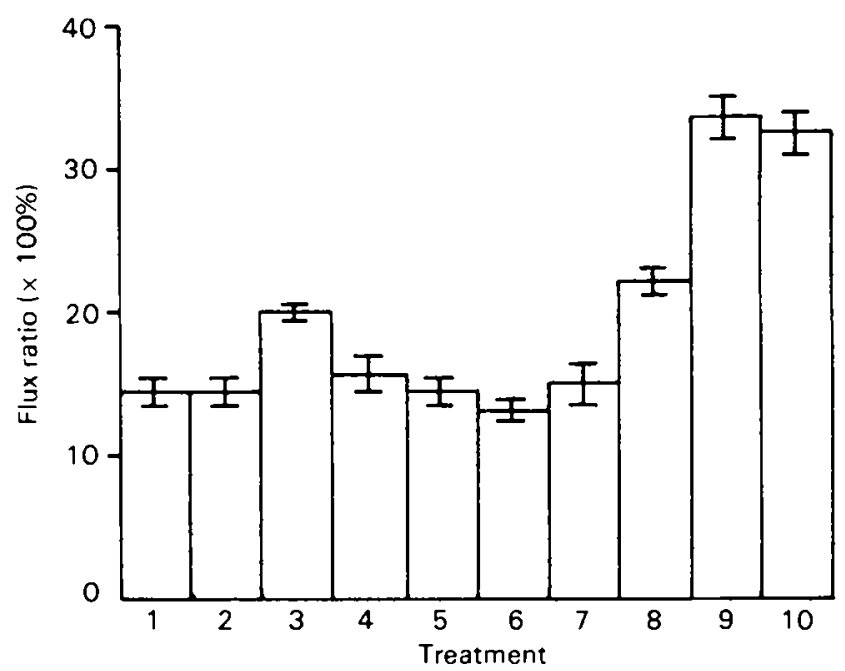

Fig. 3. Relationship between the flux through picolinate carboxylase (EC 4.1.1.45) and through tryptophan 2,3-dioxygenase ( $E C$ I.1 3.1 I.1 I) in isolated rat liver cells. Treatment of rats: I, fed; 2 , $4^{8} \mathrm{~h}$ starved; 3 , pyridoxine control; 4 , pyridoxine deficient; 5 , tryptophan; 6 , adrenalectomy; 7 , adrenalectomy + steroid; 8,3 d diabetes; 9 , 10 d diabetes; 10 , 10 d diabetes + insulin.

Cells were incubated with $100 \mu \mathrm{M}-\mathrm{L}-$-tryptophan and $20 \mathrm{~g}$ albumin/l. Rats were Sprague-Dawley, males, $150-220 \mathrm{~g}$, given standard laboratory diet. The control diet for pyridoxine deficiency contained more protein than the standard diet. Tryptophan was given as two doses of $750 \mathrm{mg} / \mathrm{kg}$ body-weight, $6 \mathrm{~h}$ apart with the second injection $6 \mathrm{~h}$ before the experiment. Dexamethasone phosphate $\left(0.5 \mathrm{mg} /\right.$ animal) was injected subcutaneously daily for $5^{-8} \mathrm{~d}$ into adrenalectomized animals. Diabetes was induced by intravenous injection of streptozotocin ( $80 \mathrm{mg} / \mathrm{kg}$ body-weight). Insulin was given intraperitoneally as follows: 2 i.u. $24 \mathrm{~h}$ after streptozotocin, then daily for $3 \mathrm{~d}$ thereafter; $3 \cdot 5$ i.u. were injected twice daily.

diabetes. It is known that picolinate carboxylase is induced by prolonged diabetes (Ikeda et al. 1965), and this implies therefore that flux through the lower part of the pathway is regulated by the activity of the carboxylase, and that quinolinate accumulation results from the 'overspill' of 3 -hydroxyanthranilate generated in the early reactions of the sequence.

Pyridoxine deficiency greatly decreases the activity of kynureninase as anticipated (Dalgliesh, 1952; Schutz et al. 1972); the flux through the enzyme in liver cells was 5.3 (SE 0.2$) \mathrm{nmol} / \mathrm{h}$ per $\mathrm{mg}$ in controls and 3.1 (SE 0.2$) \mathrm{nmol} / \mathrm{h}$ per $\mathrm{mg}$ in pyridoxine deficiency, a decrease of $42 \%$. Flux through tryptophan dioxygenase was relatively unaffected. Tyrosine aminotransferase (EC 2.6.1.5) is also dependent on pyridoxal phosphate but its activity proves less susceptible to pyridoxine deficiency. In control and pyridoxine-deficient cells respectively, the flux from tyrosine to 4 -hydroxyphenylpyruvate was 4.8 (SE O.I) and 4.0 (SE 0.1) $\mathrm{nmol} / \mathrm{h}$ per $\mathrm{mg}$, a decrease of only $17 \%$.

Tyrosine aminotransferase is the rate-limiting enzyme of tyrosine catabolism and, as such, might be expected to be controlled both acutely and chronically. We have, using techniques similar to those described previously, been able to show that enzyme activity increases with exposure to tryptophan, glucocorticoid and 
chronic diabetes. Flux through the enzyme is increased under the same conditions and also by starvation and acute diabetes (Table 1 ). The factors responsible for this divergence are again under scrutiny but one obvious candidate is 2-oxoglutarate, the second substrate for the aminotransferase.

Phenylalanine hydroxylase ( $E C$ I.I4.I6.I) regulates phenylalanine conversion into tyrosine and, hence, oxidation in liver. The enzyme is phosphorylated by a cyclic AMP-dependent protein kinase (EC 2.7.1.37) (Abita et al. 1976) which is activated by exposure to glucagon in vivo (Donlon \& Kaufman, 1978). In isolated cells, glucagon causes an increase in phenylalanine hydroxylation at low concentrations of phenylalanine (Carr \& Pogson, 1981). The dose-response to the hormone of this increased activity under physiologically-relevant conditions has been compared with that of enzyme phosphorylation in parallel incubations. The similarity of the two relationships (Fig. 4) strongly suggests that both events are causally linked (Fisher \& Pogson, 1984). This experiment would, of course, have been difficult if not impossible to perform with whole liver or in vivo.

\section{Fat oxidation in sheep liver}

Liver cells are prepared from sheep by perfusion of the caudate lobe which, although variable in size and shape, is not very different from the whole liver of a

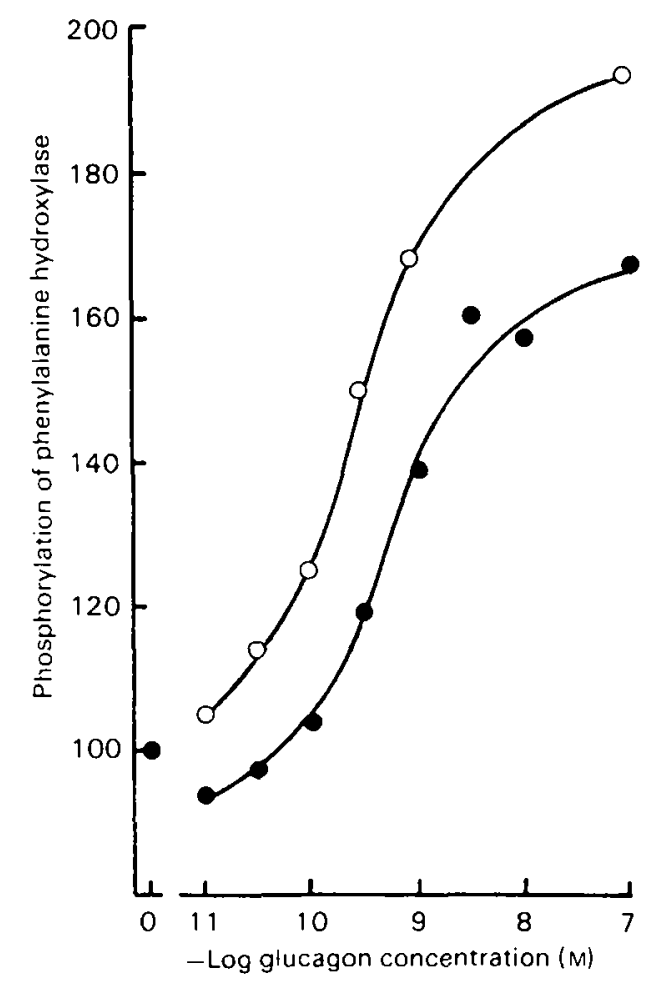

Fig. 4 The relationship between the phosphorylation of phenylalanine hydroxylase (EC I.1 4.16.1) and the flux through the enzyme in isolated rat liver cells incubated with glucagon. (O), \% of basal phosphorylation; (O), "\% of basal flux. Cells were incubated with $50 \mu \mathrm{M}-\mathrm{L}$-phenyalanine. Other conditions were as given in Carr \& Pogson (1981) and Fisher \& Pogson (1984). 


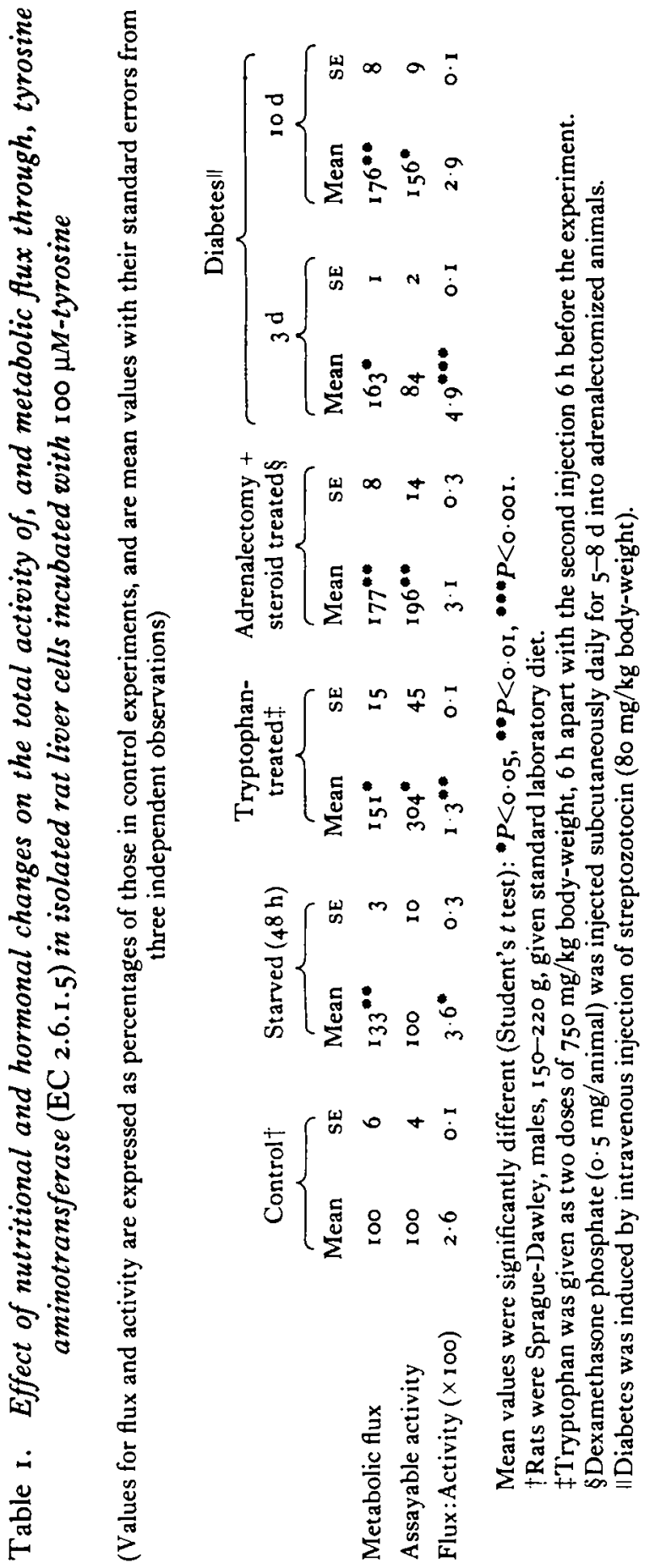


laboratory rodent. As expected, such cells convert propionate to glucose at rates higher than found with other substrates (Ash \& Pogson, 1977) and show several differences from cells from other species. Fatty acid oxidation is appreciable although lower than in the rat. When cells are derived from fed sheep, $\beta$-oxidation is accelerated by addition of carnitine (Fig. 5); in cells from starved animals, however, rates are already high and are not increased by carnitine. One explanation of these observations is that carnitine is lost during cell isolation, and that there may be little difference between fed and starved states in respect of $\beta$-oxidative capacity in vivo. Carnitine concentrations are known to be very much increased in livers of starved sheep (Snoswell \& Henderson, 1970) so that leakage might still leave sufficient for metabolic requirements. Although ketogenesis is increased in starved sheep in vivo (Katz \& Bergman, 1969) it is perhaps as likely, if not more so, that propionate is the most important factor (Fig. 5) especially because the physiological propionate concentration in portal blood is very similar to that which causes $50 \%$ inhibition of ketogenesis in cell incubations (Lomax et al. 1983). The similarity of maximal rates of ketogenesis from palmitate in cells from fed and starved sheep contrasts with observations in the rat (Christiansen, 1977) where the differences have been interpreted in terms of the role of malonylCoA as a regulator of carnitine acyltransferase I ( $E C$ 2.3.I.7) (Sugden \& Williamson, I 98r). Together with the absence of any effect of glucagon on ketogenesis in sheep cells (Pogson et al. 1983) and the low rate of fatty acid synthesis in sheep liver (Bassett, 1975; N. Brindle, C. Pogson and V. Zammit, unpublished results), this suggests that malonylCoA may play a less important role in sheep than in rat liver.

Although the availability of carnitine has no effect on octanoate oxidation by sheep liver cells, as anticipated, propionate decreases octanoate conversion to ketone bodies(Fig. 5). This suggests that propionate may inhibit ketogenesis other than at the step catalysed by carnitine acyltransferase I (Lomax et al. 1983). Once again, the use of isolated cells has pinpointed aspects for more detailed examination.

\section{Insulin degradation}

In recent studies we have found that rat liver cell suspensions with good viability by several criteria nevertheless apparently lose a considerable amount of their insulin-degrading capacity into the medium (Carpenter et al. 1983). The percentage of the activity in the medium is decreased from 57 to $29 \%$ by washing and resuspension, but still contrasts markedly with our own earlier observations with cells from another group of rats in another laboratory where such leakage was found to be negligible under otherwise similar conditions (poole et al. I982). The literature confirms that 'leakiness' is found in some laboratories and not others.

The paradoxically high level of insulin-degrading activity in the medium is explained by the demonstration that such activity in cells is stimulated several-fold by cell lysis or homogenization. A small degree of leakage therefore results in greatly enhanced total insulin degradation with a significant proportion in the medium. Perhaps insulin-degrading activity constitutes one of the better criteria for cell viability 1 


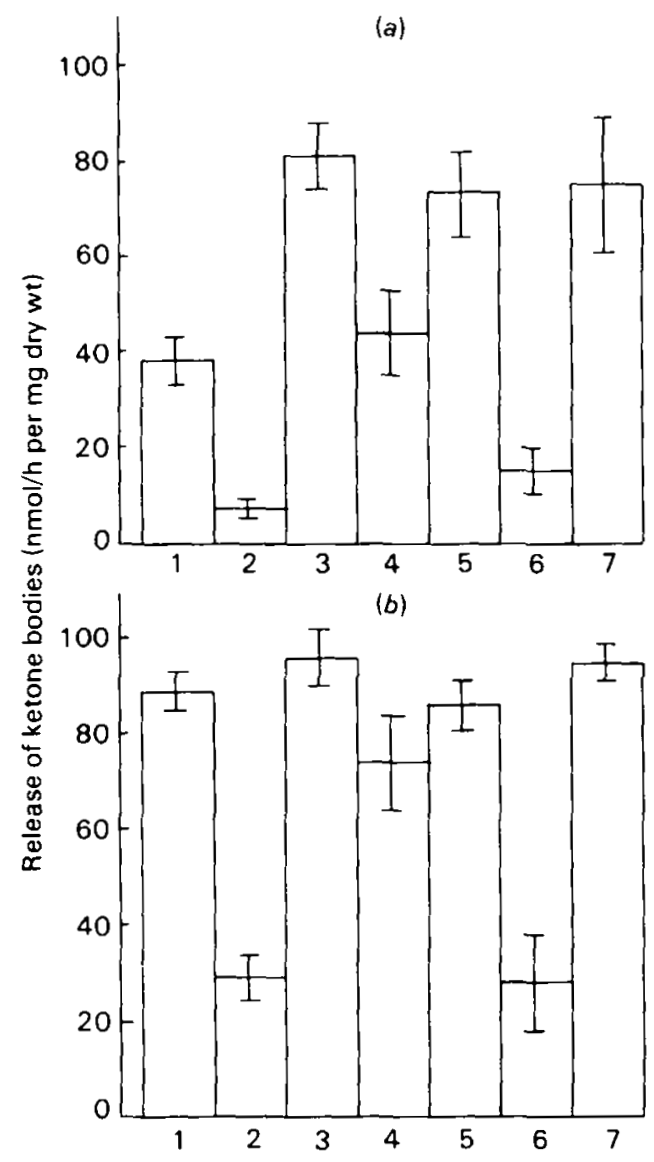

Fig. 5. The effects of starvation and fatty acids on ketogenesis in isolated sheep liver cells. The values are from Lomax et al. ( $198_{3}$ ) from which further details may be obtained. (a), Fed animals; $(b)$, starved $(48 \mathrm{~h})$ animals; 1 , palmitate; 2 , palmitate + propionate; 3 , palmitate + carnitine; 4 , palmitate + propionate + carnitine; 5 , octanoate; 6 , octanoate + propionate; 7 , octanoate + carnitine. Results are mean values, with their standard errors represented by vertical bars, from at least three independent observations.

Cells cultured for $48 \mathrm{~h}$ in several media showed extensive loss of ATP (W. Carpenter and C. Pogson, unpublished results). Use of Waymouth's MB 752/I supplemented with oleate and serum albumin, however, gives cells which, at $48 \mathrm{~h}$, have high ATP values and exhibit very little leakage of insulin-degrading activity. Thus, with careful attention to the precise conditions of culture and incubation, cell preparations with substantially-unimpaired retention of hepatic function may be obtained.

\section{Conclusions}

There is little doubt that the incautious use of isolated cell techniques can lead, and indeed has led, to the appearance of artefacts and the drawing of misleading 
conclusions. It cannot be stressed too strongly that cell preparations should be tested for viability routinely, that crucial experiments should be repeated at least three times, and that results should be interpreted with reference to what is known of normal physiology. If these guidelines are followed, then this technique can be a useful adjunct to others in the hands of those interested in the regulation of metabolic processes.

The authors are grateful to the Agricultural, Medical and Science and Engineering Research Councils for financial support.

\section{REFERENCES}

Abita, J.-P., Milstien, S., Chang, N. \& Kaufman, S. (1976). Fournal of Biological Chemistry 251, $53 \mathrm{IO}^{\mathrm{O}-5} 3^{\mathrm{I}} 4$.

Akerboom, T., van der Meer, R. \& Tager, J. M. (1979). In Techniques in the Life Sciences: Biochemistry, vol. B2/I, p. B205 [H. L. Kornberg, J. C. Metcalfe, D. H. Northcote, C. I. Pogson and K. F. Tipton, editors]. Amsterdam: Elsevier North Holland.

Allan, E. H., Chisholm, A. B. \& Titheradge, M. A. (1983). Biochemical fournal $212,417-426$.

Ash, R. \& Pogson, C. I. (1977). Biochimica et Biophysica Acta 496, 475-483.

Badawy, A. A. -B. (I981). Biochemical fournal r96, 21 7-224.

Badawy, A. A. -B., Welch, A. N. \& Morgan, C. J. (1981). Biochemical fournal r98, 309-314.

Bassett, J. M. (1975). In Digestion and Metabolism in the Ruminant, pp 383-398 [I. W. McDonald and A. C. Warner, editors]. Armidale, Australia: University of New England Publishing Unit.

Bellemann, P., Gebhardt, R. \& Mecke, D. (1977). Analytical Biochemistry 81, 408-41 5.

Bender, D. A., Magboul, E. I. \& Wynich, D. (1982). British Yournal of Nutrition 48, I 19-127.

Bengtsson, B. G., Kiessling, K-H., Smith-Kielland, A. \& Mørland, J. (1981). European fournal of Biochemistry I $18,59 \mathrm{I}-597$.

Berry, M. N. (1974). Methods in Enzymology 32, 625-632.

Berry, M. N. \& Friend, D. S. (1969). Fournal of Cell Biology 43, 506-520.

Bhargava, P. M. (1968). Science and Culture (Calcutta) 34, $105^{-127 .}$

Byard, J. L., Reese, J. A. \& Knadle, S. A. (1983). In Isolation, Characterization and Uses of Hepatocytes, pp. $69-76$ [R. A. Harris and N. W. Cornell, editors]. New York: Elsevier Biomedical.

Carpenter, W. R., Pogson, C. I., O'Connor, K. J. \& Lazarus, N. R. ( 1983 ). Biochemical Society Transactions I1, 393-394.

Carr, F. P. A. \& Pogson, C. I. (1981). Biochemical fournal 198, 655-660.

Cho-Chung, Y. S. \& Pitot, H. C. (1 967). Journal of Biological Chemistry 242, $1192-1198$.

Christiansen, R. Z. (1977). Biochimica et Biophysica Acta 488, 249-262.

Christiansen, R. Z. \& Bremer, J. (1976). Biochimica et Biophysica Acta 448, 562-577.

Cighetti, G., Galli, G. \& Galli-Kienle, M. (1983). European Fournal of Biochemistry 133, $573-578$.

Cook, J. S. \& Pogson, C. I. (1981). Biochemical Society Transactions 9, 404-405.

Cook, J. S. \& Pogson, C. I. (1982). Biochemical fournal 204, 307-312.

Cook, J. S. \& Pogson, C. I. (1983). Biochemical Fournal 2 I4, 5 I 1-516.

Cornell, N. W., Lund, P. \& Krebs, H. A. (1974). Biochemical fournal 142, 327-337.

Crisp, D. M., Sörman, A. E., Beirne, J. M., Orton, T. C. \& Sturdee, A. P. (1982). European fournal of Biochemistry $123,377-381$.

Dalgliesh, C. E. (1952). Biochemical fournal 52, 3-14.

Dickson, A. J., Marston, F. A. O. \& Pogson, C. I. (1981). FEBS Letters 127, 28-32.

Dickson, A. J. \& Pogson, C. I. (1977). FEBS Letters 83, 27-32.

Dickson, A. J. \& Pogson, C. I. (1980). Biochemical Journal x 86, 35-45.

Donlon, J. \& Kaufman, S. (1978). Fournal of Biological Chemistry 253, 6657-6659. 
Elliott, K. R. F. (1979). In Techniques in the Life Sciences: Biochemistry, vol. B2/r, p. B204 [H. L. Kornberg, J. C. Metcalfe, D. H. Northcote, C. I. Pogson and K. F. Tipton, editors]. Amsterdam: Elsevier North Holland.

Elliott, K. R. F., Ash, R., Pogson, C. I., Smith, S. A. \& Crisp, D. M. (1976). In Use of Isolated Liver Cells and Kidney Tubules in Metabolic Studies, pp. 139-143 [J. M. Tager, H-D. Söling and J. R. Williamson, editors]. Amsterdam: Elsevier North Holland.

Farrell, R. \& Lund, P. (1983). Bioscience Reports 3, 539-543.

Fisher, M. J. \& Pogson, C. I. (1984). Biochemical Yournal 219, 79-85.

Fry, J. R., Jones, C. A., Wiebkin, P., Bellemann, P. \& Bridges, J. W. (1976). Analytical Biochemistry $7 \mathrm{I}, 34 \mathrm{I}-35^{\circ}$.

Fuller, B. J., Morris, G. J., Nutt, L. H. \& Attenburrow, V. D. (1980). Cryo-Letters 1, 139-146.

Gankema, H. S., Laanen, F., Groen, A. K. \& Tager, J. M. (1981). European Fournal of Biochemistry $119,409-414$.

Gebhardt, R. \& Mecke, D. (1979). Experimental Cell Research 124, 349-359.

Gordon, P. B. \& Seglen, P. O. (1982). Experimental Cell Research 142, 1-I4.

Guguen-Guillouzo, C., Baffet, G., Clement, B., Begue, J-M., Glaise, D. \& Guillouzo, A. (1983). In Isolation, Characterization and Use of Hepatocytes, pp. 105-110 [R. A. Harris and N. W. Cornell, editors]. New York : Elsevier Biomedical.

Guguen-Guillouzo, C., Campion, J. P., Brissot, P., Glaise, D., Launois, B., Bourel, M. \& Guillouzo, A. (1982). Cell Biology International Reports 6, 625-628.

Harris, R. A. \& Cornell, N. W. (editors) (1983). Isolation, Characterization and Use of Hepatocytes, New York Elsevier Biomedical.

Ichihara, A., Hakamura, T. \& Tanaka, K. (1982). Molecular and Cellular Biochemistry 43, I 45-160.

Ikeda, M., Tsuji, H., Nakamura, S., Ichiyama, A., Nishizuka, Y. \& Hayaishi, O. (1965). Fournal of Biological Chemistry 240, $1395^{-1} 401$.

Jungermann, K. \& Katz, N. (1982). In Metabolic Compartmentation, pp. 411-435 [H. Siess, editor]. London: Academic Press.

Jungermann, K. \& Sasse, D. (1978). Trends in Biochemical Science 3, 198-202.

Katz, M. L. \& Bergman, E. N. (1 969). American fournal of Physiology 2 16, 953-960.

Krebs, H. A., Cornell, N. W., Lund, P. \& Hems, R. (1974). In Regulation of Hepatic Metabolism, pp. 726-75o [F. Lundquist and N. Tygstrup, editors]. New York: Academic Press.

Krebs, H. A., Hems, R. \& Tyler, B. (1976). Biochemical fournal 1 58, 341-353.

Lomax, M. A., Donaldson, I. A. \& Pogson, C. I. (1983). Biochemical fournal 214, 553-560.

Lowitt, S., Szentiranyi, A. \& Williams, J. F. (1981). Biochemical Pharmacology 30, 1999-2006.

McCallum, R. E. (1981). In Pathophysiological Effects of Endotoxins at the Cellular Level, pp. 99-I I 3 [J. A. Majde and R. J. Person, editors]. New York: Alan R. Liss.

McMenamy, R., Kleineke, J., Roil, W. \& Söling, H-D. (1981). Analytical Biochemistry Ir 2, $117-127$.

Muñoz-Clares, R. A., Lloyd, P., Lomax, M. A., Smith, S. A. \& Pogson, C. I. (1981). Archives of Biochemistry and Biophysics 209, $713-717$.

Nelson, K. F., Acosta, D. \& Bruckner, J. V. (1982). Biochemical Pharmacology 31, 22 I I-22 I4.

Noviki, D. L., Irons, G. P., Strom, S. C., Jirtle, R. \& Michalopoulos, G. (I982). In Vitro 18, 393-399.

Paine, A. J. \& Hockin, L. J. (1980). Biochemical Pharmacology 29, 321 5-3218.

Palese, M. \& Tephly, T. R. (1975). Journal of Toxicology and Environmental Health 1, $13-24$.

Parli, C. J., Krieter, P. \& Schmidt, B. (1980). Archives of Biochemistry and Biophysics 203, I6I-I 66 .

Pogson, C. I., Elliott, K. R. F., Lomax, M. A., Muñoz-Clares, R. A. \& Smith, S. A. (1983). In Isolation, Characterization and Use of Hepatocytes, pp. 21-30 [R. A. Harris and N. W. Cornell, editors]. New York: Elsevier Biomedical.

Poole, G. P., O'Connor, K. J., Lazarus, N. R. \& Pogson, C. I. (1982). Diabetologia 23, 49-53.

Probst, I., Schwartz, P. \& Jungermann, K. (1982). European fournal of Biochemistry 126, $271-278$.

Reese, J. A. \& Byard, J. L. (198x). In Vitro 1 7, 935-940.

Sattler, C. A., Michalopoulos, G., Sattler, G. L. \& Pitot, H. C. (1978). Cancer Research 38, 1539-1549. 
Schutz, G., Chow, E. \& Feigelson, P. (1972). Journal of Biological Chemistry 247, 5333-5337.

Seglen, P. O. (1 976). Methods in Cell Biology $13,29-83$.

Smith, S. A., Carr, F. P. A. \& Pogson, C. I. (I981). Biochemical Yournal 192, 673-686.

Smith, S. A. \& Pogson, C. I. (1980). Biochemical fournal 186, 977-986.

Snoswell, A. M. \& Henderson, G. D. (1970). Biochemical fournal I 19, 59-65.

Stanley, P. E. \& Williams, S. G. (1969). Analytical Biochemistry 29, 381-392.

Sturdee, A. P., Beirne, J. M., Sörman, A. E., Orton, T. C. \& Crisp, D. M. (1983). Life Science 32, $1463-1469$.

Sugden, M. C. \& Williamson, D. H. (1981). In Short-Term Regulation of Liver Metabolism, pp. 291-309 [L. Hue and G. Van de Werve, editors]. Amsterdam: Elsevier North Holland.

Tager, J. M., Söling, H-D. \& Williamson, J. R. (editors) (1976). Use of Isolated Liver Cells and Kidney Tubules in Metabolic Studies. Amsterdam: Elsevier North Holland.

van der Meer, R. \& Tager, J. M. (1976). FEBS Letters 67, 36-40.

Viña, J., Hems, R. \& Krebs, H. A. (1978). Biochemical Yournal I 70, 627-630.

Viña, J., Saez, G. T., Wiggins, D., Roberts, A. F. C., Hems, R. \& Krebs, H. A. (1983). Biochemical fournal $212,39-44$.

Zuurendonk, P. F., Tischler, M., Akerboom, T., van der Meer, R., Williamson, J. R. \& Tager, J. M. (1979). Methods in Enzymology 56, 207-216. 